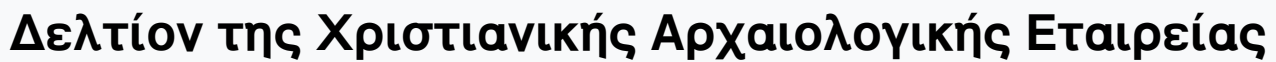

Tó 18 (1995)

$\Delta \varepsilon \lambda$ Tíov XAE 18 (1995), Пعрі́оסос $\Delta^{\prime}$

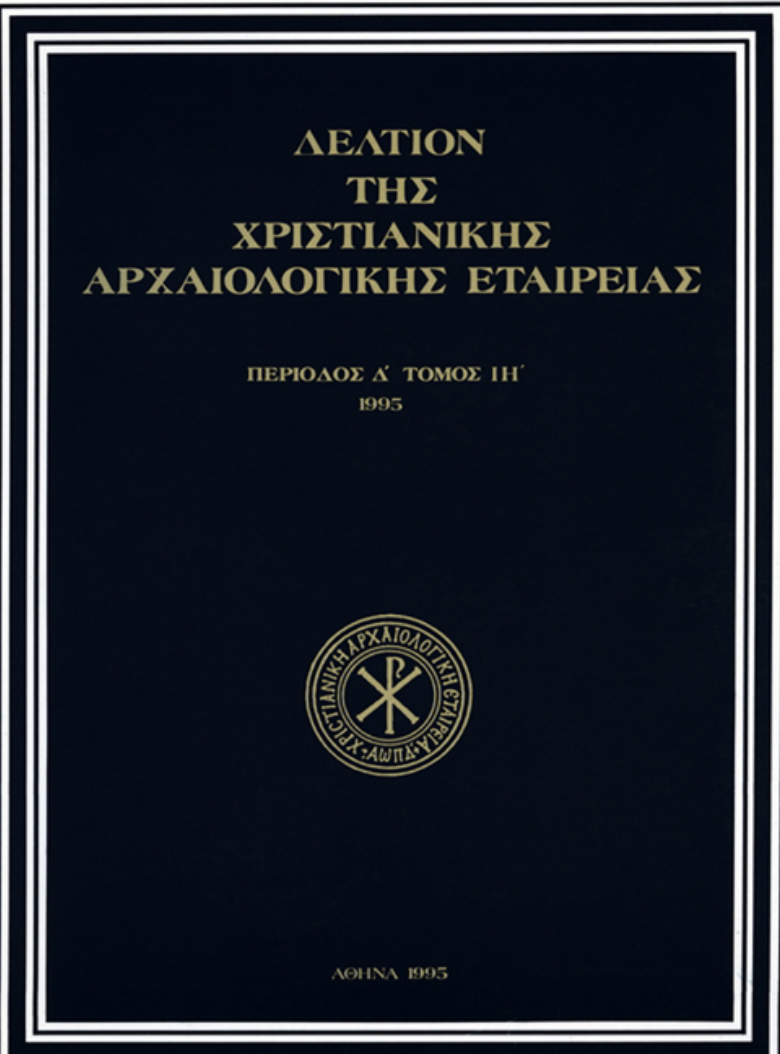

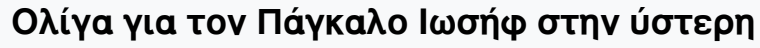

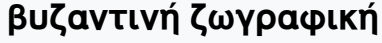

Branislav TODIĆ

doi: $\underline{10.12681 / \text { dchae. } 1145}$

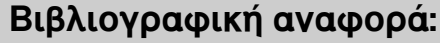

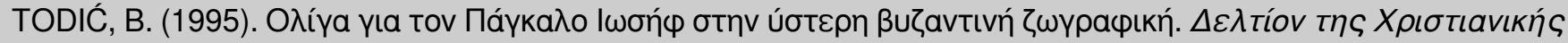
Архаıолоүıки́с Eтаıрєі́ac, 18, 89-96. https://doi.org/10.12681/dchae.1145 


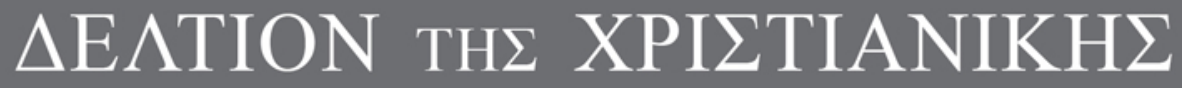 APXAIO $\Lambda$ OГIKH $\Sigma$ ETAIPEIA $\Sigma$}

A Note on the Beauteous Joseph in Late Byzantine Painting

Branislav TODIĆ

$\Delta \varepsilon \lambda \tau$ tíov XAE 18 (1995), Пв@íodos $\Delta^{\prime} \bullet \Sigma \varepsilon \lambda .89-96$

A@HNA 1995 


\section{Branislav Todić}

\section{A NOTE ON THE BEAUTEOUS JOSEPH IN LATE BYZANTINE PAINTING}

$\mathrm{T}_{\mathrm{l}}$ in Byzantine art articulated long since is constantly being augmented by new studies, based less on fresh material but rather on differing interpretations of the already published Joseph cycles in fresco, miniature and the applied arts. The authors vary to a considerable extent in their explication of representations of the righteous Joseph, a fact which has inspired us to return to these representations and offer a new interpretation based, above all, on the texts used at services in the Byzantine church. It seems important, already at this moment, to point out the admonition expressed by A. Grabar that it is virtually impossible to find a uniform explanation for all the preserved images of the cycles due to the diversity of their programmes and an iconography with a tradition of its own ${ }^{1}$. Indeed, the illustration of the Biblical text in the Vienna Genesis, the Cotton Bible or the miniatures of the two Vatican Octateuchs (Vat. gr. 747 and Vat. gr. 746) are of an anecdotal nature and are tied closely to the Old Testament text (Genesis 37-50). Such a choice of images could hardly be tied to the exegesis of the Christian fathers or to liturgical reading $\mathrm{s}^{2}$.

Those who have written on Joseph, especially $M$. Schapiro, S. Der Nersessian, A. Grabar, G. Montanari and M.-D. Gauthier-Walter ${ }^{3}$, saw in him a role-model for rulers or bishops or a symbol of the good ruler in general, a presumption difficult to accept as an overall and universal interpretation for two reasons: first, for the lack of such evidence in written sources, and, second, because of the liturgical function of the texts on Joseph which seems to have been disregarded and the appearance of his image and scenes of his life on church walls thus to have remained without explanation. Namely, one should not disregard the fact that Joseph is rarely mentioned as an ideal ruler, as opposed to Moses, Hosea, David or Solomon, in literature or other written sources, just as his rare portraits always have a different meaning. Almost as a rule, Joseph's turbulent life is represented in the figural arts through a more or less extensive cycle, with its numerous temptations and difficulties, sufferings and triumphs. Such a life could hardly have served as an analogy, much less an example, for the life of an ideal ruler $^{4}$. The extirpation of a single scene (Joseph's triumph) and the formation of an interpretation on such a basis is methodologically un-acceptable because it leads to incomplete and even wrong conclusions.

The early fathers of the Church (fourth-fifth century) who have written on Joseph, whether in the form of specific works or as a part of various sermons -Tertullianus, Ambrose of Milan, Gregory of Nazianzus, Ephraim the Syrian, Basil, the bishop of Seleucis, John Chrysostomos- speak of him mainly from two aspects: Joseph is, first, the arch-image of Christ, and then an exemplar of those who, through their constant faith in the Lord, have overcome the devil's numerous temptations and who, as a reward, receive eternal wreaths from the Almighty ${ }^{5}$. Saint John Chrysostomos builds this metaphore on contrasts between Joseph and Pentefry's wife:

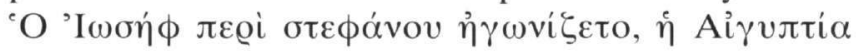

1. A. G r a b a r, Les cycles d'images byzantins tirés de l'histoire biblique et leur symbolisme princier, Starinar XX (1969), p. 134.

2. P. Fabre had already, very reasonably, pointed that out (Le développement de l'Histoire de Joseph dans la littérature et dans l'art au cour des douze premiers siècles, Mélanges d'archéologie et d'histoire, 1921-1922, p. 193-211), but the results of his very good study have lately been unjustly ignored.

3. M. Schapiro, The Joseph Scenes on the Maximianus Throne in Ravenna, GBA XL (1952), p. 23-28. S. Der Nersessian, The Illustrations of the Homilies of Gregory of Nazianzus, Paris. gr. 510. A Study of the Connections between Text and Images, DOP 16 (1962), p. 223-224. Grabar, op.cit., p. 133-137. G. Montanari, Giuseppe l'Ebreo della Cattedra di Massimo: prototipo del buon guverno? FelRav CXXVII-CXXX (1985), p. 305-322. M.-D. Gauthier-Walter, Joseph, figure idéale du roi?, CahArch 38 (1990), p. 25-36.

4. Grabar, op.cit., p. 134

5. PG 36, col. 225-228, 244, 545, 593; 56, col. 587-590; 62, col. 759764; 85, col. 112-125. Tvorenija iže vo svjatyh otca našego Efrema Sirina, II, Moscow 1849, p. 116-146. F a b r e, op.cit. (note 2), p. $195 \mathrm{ff}$. (for Tertullianus). S ch a p i r o, op.cit. (note 3), p. 29ff. (for St Ambrose of Milan). 


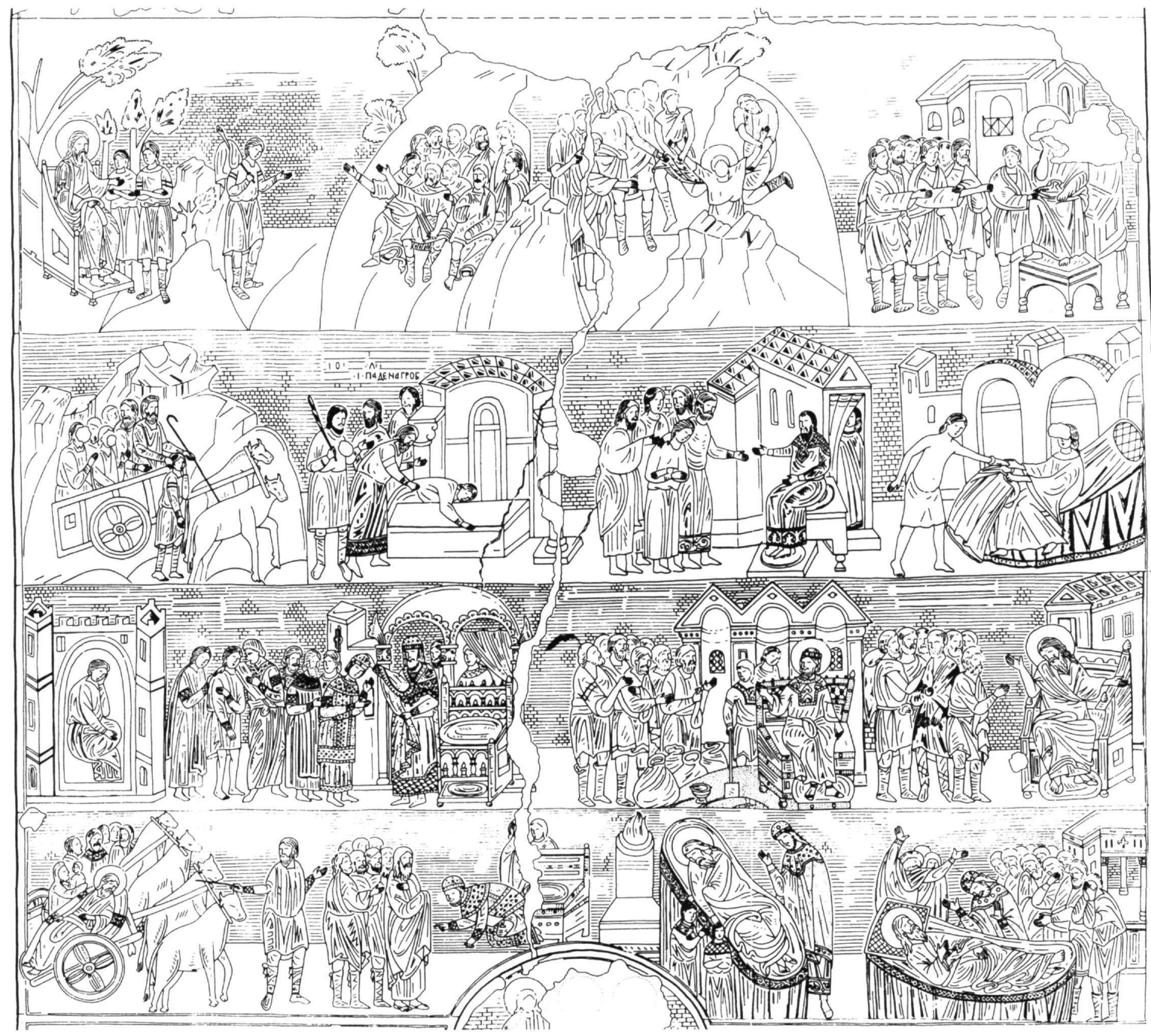

Fig. I. Sopocani. The Joseph is Cicle. 1263-1268 (drawing by B. Zivkovic).

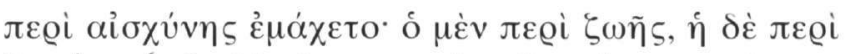
$\theta \alpha v \alpha \dot{\tau} v^{6}{ }^{6}$. In his interpretation Joseph grows into a moral beacon for Christians in general, an example to

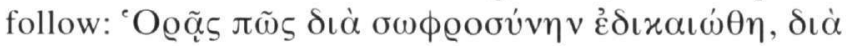

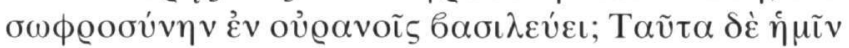

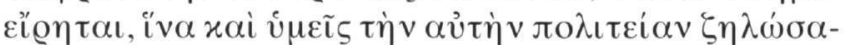

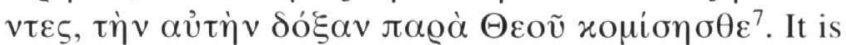
my opinion, and in that respect I agree with P. Fabre, that it was this didactic sermon of St John Chrysostomos which was crucial for the popularity of the Joseph theme in medieval art- it was addressed to emperors and bishops (especially responsible for the folk under their care) but likewise to all believers, as attested by the fact that the episode speaking of Joseph's chastity in the quarters of the Egyptian lady is never missing from the otherwise very variable choice of scenes of the Joseph's 
cycle as well as by the allegories of virtues accompanying this cycle in the church of San Marco in Venice ${ }^{8}$. That, most probably, was the reason behind the appearance of a Joseph cycle in the illumination of a sermon by

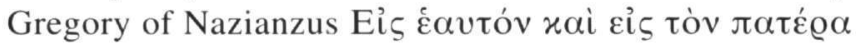

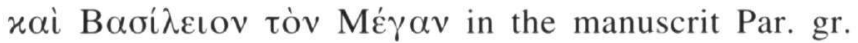
$510^{9}$, as an illustration of moral constancy and the power of faith, therefore, an example to those addressed by the author ${ }^{10}$. It is in this miniature that we first see a different edition of the cycle which has precluded the illustrative quality characteristic of the earlier monuments: all details unimportant for emphasizing Joseph's suffering, his chastity and his constancy in the faith of his fathers and his final triumph (Joseph's dreams, episodes with the cup bearer and the baker, the pharaoh's dreams and their interpretation, etc.) have been excluded, only those scenes of a very probable didactic quality within the cycle as a whole were represented.

After the ninth century representations of Joseph's cycle become scarce in Byzantine art. The carving on a box from Sens (tenth-eleventh century) and the miniatures of Vat. gr. 747 (eleventh century) and Vat. gr. 746 (twelfth century) prove that the anecdotal-illustrative form was kept in use. A close following of the text is apparent in illustrations of Psalm CIV, while the iconography of the scenes follows that of cycles created after the Genesis text ${ }^{11}$, as is the case with psalters of the late Byzantine epoch $^{12}$, the only difference being the scenes of Joseph's triumph with elements of courtly ceremonial and imperial iconography which become increasingly popular in the illumination of these psalters.

An abundance of material in manuscripts dating from the ninth to the thirteenth century testifies that the memory of Joseph had definitely been included into church services and that it was tied to two dates -the Sunday of the Holy Ancestors and the Monday of the Holy Week- thus indicating that the Orthodox Church had designated Joseph as a forefather and a prototype of Christ. It is characteristic that the only sermon read on services preceeding Christmas is that of St Ephraim the Syrian,

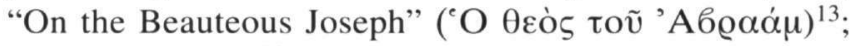
the same sermon ${ }^{14}$, or that of St John Chrysostomos Eis

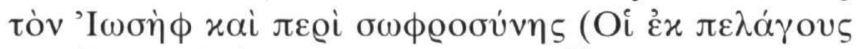

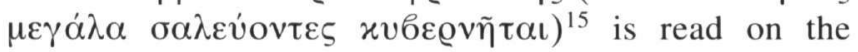
services of Good Monday. In his sermon St Ephraim the Syrian offers first a series of parallels between Joseph and Christ and then tells the story of Joseph's life, dwelling especially on the adversities with his brothers, the resistance of sin with the Egyptian lady, his rise to glory in Egypt, the proceedings with his brothers and Jacob's coming to Egypt ${ }^{16}$. The sermon of St John Chrysostomos is more didactic, it speaks of Joseph as an Old Testament personification of virtues, just like Job, Moses, David, Daniel and Susanna. He dwells mainly on the description of Joseph's rejection of the sinful desire of Pentefry's wife and then gives a brief account of his further exploits: the interpretation of the cup bearer's dreams and the arrival of his brothers, to finish off with drawing a parallel between the sale of Joseph by his brothers and Judas' betrayal of Christ $^{17}$. In hymns sung on Good Monday, the Triodus of Andrew of Crete ${ }^{18}$, two hymns by Roman Melodus ${ }^{19}$, as well as in that best known, though anonymous, hymn, still

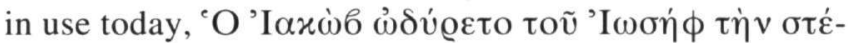

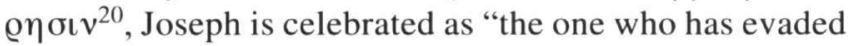

6. PG, 56, col. 588

7. Ibid., col. 590 .

8. O. Demus, The Mosaics of San Marco in Venice, II/1, ChicagoLondon 1984, p. 97.

9. PG, 35, col. 828-832; H. O m o n t, Miniatures des anciens manuscrits grecs de la Bibliothèque Nationale du VIe au XIVe siècle, Paris 1929, pl. XXI.

10. The connection between the text and the image exists only in this methaphorical sense, not literally, as was pointed out by Serarpie Der Nersessian, op.cit. (note 3), p. 214-215. She interpreted the closing scenes of the cycle through imperial iconography (p. 223), which was later to be adopted in science, but her interpretation was also uncritically set as an absolute principle, see also M.-D. G a u th i e r - W a l t e r, op.cit. (note 3), p. 32-33.

11. S. Dufrenne, L'illustration des psautiers grecs du moyen âge, I, Paris 1966, pl. 22, 38, 57. S. Der Nersessian, L'illustration des psautiers grecs du moyen âge, II, Paris 1970, fig. 225-226.

12. Der Serbische Psalter, Textband, Wiesbaden 1978, p. 230-232; Faksimile, Wiesbaden 1983, fols $135-135 v$, fol. 136; A. Džurova, Tomičov psaltir, Sofia 1990, I, p. 106; II, fols 179-179v; S. D u fre n n e, Tableaux synoptiques de 15 psautiers médiévaux, Paris 1978.

13. A. Eh rh a rd, Überlieferung und Bestand der hagiographischen und homilitischen Literatur der griechischen Kirche, I.III, 2. Häfte, $1 / 2$ Lieferung, Berlin - Leipzig 1952, p. 156, 165, 170, 183, 185, 200, 237, $244,352,414,415$.

14. Ibid., p. 290, 296, 300, 304, 313 .

15. Ibid., p. 162, 262.

16. The Greek text of the sermon was published by Assemani, inaccessible to us, so we use the Russian translation of his publication: Tvorenija iže vo svjatih otca našego Efrema Sirina, II, p. 116-146.

17. PG, 56, col. 587-590.

18. E. M e r c e n i e r, La prière des églises de rite byzantin, II. 2, Mon. de Chevetogne 1948, p. 96-99.

19. Romanos le Mélode, Hymnes, I, Paris 1964, p. 202-245, 260293.

20. Arhim. A m fil oh i j, Kondakarij v grečeskom podlinnike XII-XIII v. po rukopisi moskovskoj Sinodal'noj biblioteki no 437, Moscow 1879 , p. 144. Mercen ie r, op.cit., p. 99. 


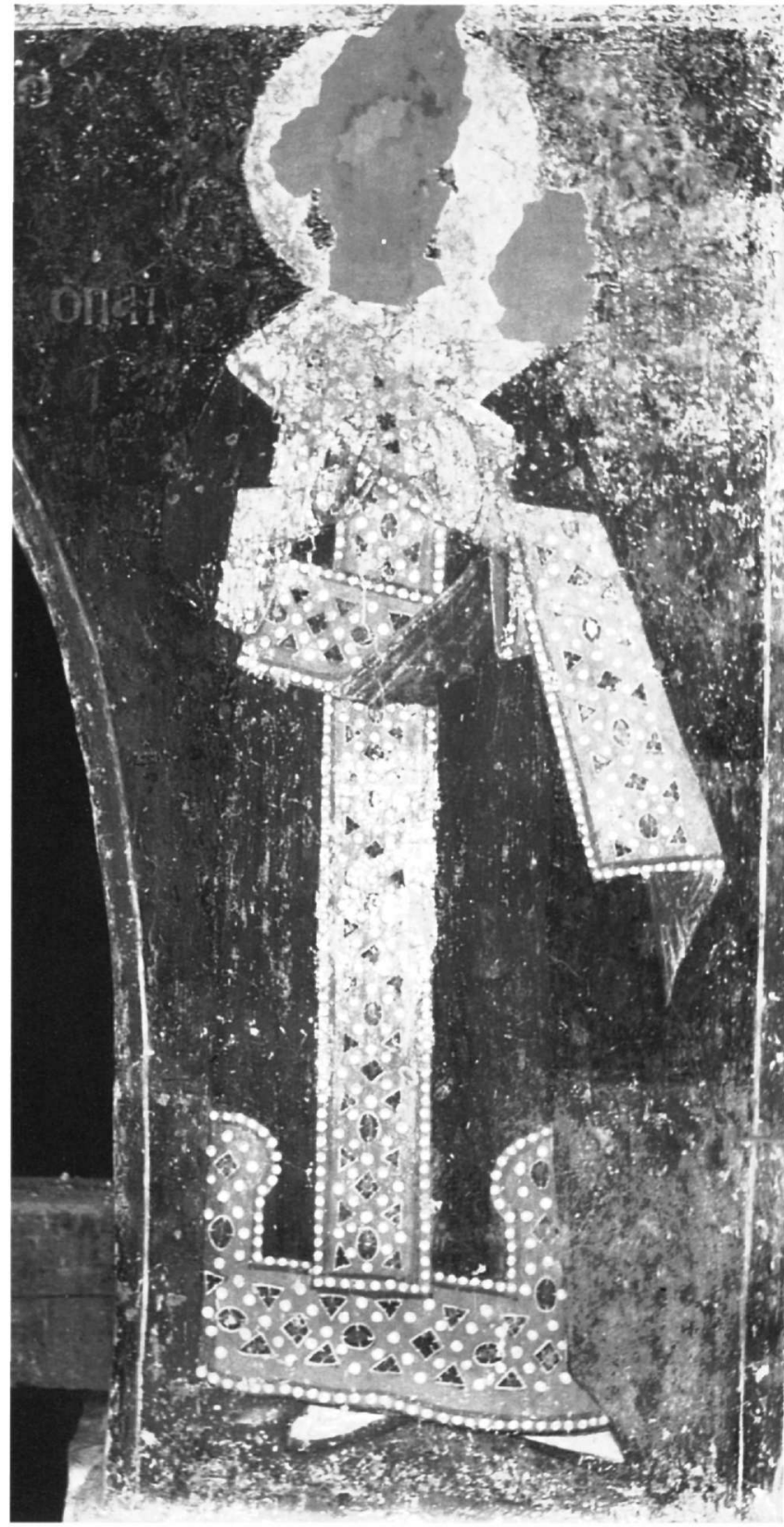

Fig. 2. Staro Nagoričino. The Beauteous Joseph. 1316-1318.

sin and gained the appearance of the image and the chastity and the true symbol of Christ" 21 .

We have, thus far, quoted the most significant texts meant to be read or sung at church services. They represent the framework delineating the bounds out of which one should not venture when interpreting figural representations of Joseph, especially so when they appear as a part of a church decoration programme. Which of its meaning was to be more emphasized -whether the christological or the didactic- depended on the context in which it was employed, and that means the location in the church interior where it was painted and the other scenes which surrounded it. In Early Christian churches, for example, the representations of Joseph as a prototype of Christ's suffering were predominant: in the Constantinian Lateran basilica of St John (fourth century) the scene of "Brothers Selling Joseph off" corresponds to that of the "Betrayal of Judas", as was also the case in a certain basilica in Ravenna, attested by Rusticus Elpidius $^{22}$. In late Byzantine art, however, the "Sacrifice of Abraham" becomes the most favored prefiguration of Christ's passion, while the pictures of Joseph's cycle loose such connotation ${ }^{23}$.

It is characteristic of late Byzantine art that Joseph begins to be portrayed as a single figure, among the other Old Testament righteous. Towards the end of the thirteenth century, a figure of the Beauteous Joseph appears in the Omorphi Ecclessia in Athens (O ПРОФHTHC I $\Omega \mathrm{CH} \Phi$ O ПА[N]KA $\Lambda$ OC) as an Old Testament witness of Christ, above whom he is painted; his role as a prophet is further underlined by the text on his unrolled scroll $^{24}$. The services of the two weeks preceding Christmas are dedicated to the memory of Christ's human ancestors and in general to all the righteous of the Old Testament who had awaited his coming ${ }^{25}$. In the Service of the Forefathers many names are mentioned, among them those of Jacob, Joseph, Job, Levi, etc. We have already seen that the "Sermon on Joseph" by St Ephraim the Syrian is read before Christmas which presented the painters with the opportunity to include the figure of Joseph in the series of Old Testament personages painted during the thirteenth and the fourteenth century in the uppermost zones of churches, around apses or in domes above narthexes. Since it is the function of these paintings with Christ's ancestors, shown one beside the other, to demonstrate Christ's incarnation, Joseph is very often left out for he was not an ancestor of Christ in flesh (Protaton, Kilisse Kamii in Constantinople, the Holy Apostles in Thessaloniki, the King's Church in Studenica and other examples). Occasionally, however, he is shown as a part of this group of saints, based on the mentioned readings before Christmas as well as on the Gospel of Matthew, and was, thus, incorporated in the iconography of Christ's incarnation. In the church of the Virgin Perivleptos in Ohrid (1295) we find a row of medallions painted on the triumphal arch before the apse with Christ Emmanuel at the summit flanked by the archangels Michael and Gabriel and numerous busts of the Old Testament righteous. Among them there stands a portrait of the Beauteous Joseph (O $\triangle \mathrm{IK}[\mathrm{AIOC}] \mathrm{I} \Omega \mathrm{CH} \Phi$ 
Hamann-Mac Lean seems to notice its christological significance but not even he relinquishes the thesis of Ljubinković that this cycle stands also as the prototype of the lives of the Serbian saints Simeon and Sava ${ }^{35}$. Let us, first, remind that the cycle is to be found on the western wall of the narthex and consists of the following scenes arrayed in four zones: Jacob sends Joseph to his brothers, Joseph finds his brothers at Sechem, Brothers throw Joseph into a pit, A blooded shirt is shown to Jacob; Joseph travels with the Ismaelite merchants to Egypt, Joseph on Rachel's grave, Joseph is sold to Pentefry, Joseph's chastity before Pentefry's wife, Joseph in prison, Joseph led out of prison, the Pharaoh designates Joseph as governor, Joseph distributes grain to his brothers, Brothers inform Jacob of Joseph; Jacob's arrival in Egypt, Joseph welcomes Jacob, Jacob blesses Joseph's sons, Jacob's death. Beneath this cycle there are standing figures of the holy emperor Constantine and Helen, St Paul of Thebes with a sermon on salvation written on an unfolded roll and the figures of two holy hymnographers also bearing rolls. The northern wall is occupied by a Last Judgement and, in the lowest zone, the death scene of the Serbian queen Anna Dandolo. On the eastern wall there are depictions of the Last Supper and the seven oecumenical and one local council, an enthroned Christ and, in the southeast corner, the donor, king Uroš I with family, before the Virgin.

The location of the Joseph cycle in Sopoćani, between the Tree of Jesse and the Last Judgement, was, apparently, crucially influenced by the sermon of St Ephraim the Syrian on Joseph, read, as we have already seen, on the eve of Christmas and on Good Monday. At the very beginning Ephraim says: "For this young man, Joseph, was since his boyhood days the personification of the two comings of Christ: the first, that through the Virgin Mary, and the second, that by which all shall be set into fear" 36 . This is one of the rare parallels between Joseph and Christ from the Last Judgement. It is of an anagogical nature but must, nevertheless, be disregarded when interpreting the Joseph cycle, located by the Last Judgement not only in Sopoćani but in the Hagia Sophia in Ohrid as well. St Ephraim dwells only on those episodes of Joseph's long life which can be given a christological interpretation or on those whose didactic character is easily pointed out: Jacob sends Joseph to his brothers ("just as the Lord was sent forth from the bosom of the Father to save us all") ${ }^{37}$, Joseph approaches his brothers, Brothers sell Joseph off, Joseph's arrival in Egypt, Joseph refuses to sin with the Egyptian woman, Joseph in prison, The leading of Joseph out of prison, Joseph takes up government over entire Egypt, The arrival of Joseph's brothers in Egypt, Joseph appears before his brothers ("so will it be on that terrible day when the Lord comes on clouds of air, He shall sit on the throne of His Kingdom and before Him shall be brought those who have been tied up by fearsome angels, those who have denied His reign") ${ }^{38}$, Jacob's arrival in Egypt. All of the above episodes found their place on the Sopoćani fresco, while those less significant in regard of the basic idea of the painting were left out. St Ephraim had, after all, also just mentioned without any further description, the dreams of Joseph, the cup bearer and the baker and their interpretation, for example -episodes otherwise widely discussed in the Book of Genesis ( 37 , $5-11 ; 40,5-13 ; 41,1-32)$. On the other hand, he did introduce an apocryphal detail to his sermon, that of Joseph's lamentation on Rachel's grave, a scene exhaustively illustrated by the painters in Sopoćani, closely following the text: upon seeing his mother's grave, Joseph cries embracing it $^{39}$, while the Ismaelite merchants threaten him (one is shown with a raised club in his hand) and lift him up from the sepulchre ${ }^{40}$.

Joseph's cycle in Sopoćani is, therefore, beyond any

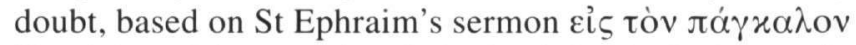
'I $\omega \sigma \eta \dot{\phi} \phi$ and its meaning is both christological (certain episodes of Joseph's life are arch-images of Christ's incarnation, his Passion and his Second Coming) and didactic. In Sopoćani, Joseph is not the personification of an ideal ruler or a bishop, but one of the righteous "who has evaded sin and gained the appearance of the image and the chastity and the true symbol of Christ" (the Triodus of Saint Andrew of Crete on vespers) ${ }^{41}$. As such, Joseph could stand as an example to both rulers and bishops just as he could to Christians in general, thus, also, to the patron of Sopoćani, the Serbian king Uroš I, portrayed on the opposite wall. The influence of imperial iconography on certain of the scenes of the cycle is not to be disputed at all ${ }^{42}$, but the cycle as a whole should not, vice versa, automatically be characterized as imperial.

The mainly didactic significance was preserved also in the Joseph cycle at the Hagia Sophia in Ohrid, painted ca 1355 , in the open gallery on the upper floor of the narthex. True, we have here a cycle based on a literary source different from that of Sopoćani which, in its forty episodes approaches the extensive cycle of San Marco in Venice. The iconography of the scenes is also different, it follows more closely the text of Genesis and combines elements of imperial iconography. By unfolding over all four walls of the narthex and its relation to the surrounding themes, the cycle in Ohrid keeps the basic meaning of a didactic story supplemented by an eschatological note which permeates the programme of 
the frescoes in this space ${ }^{43}$. The cycle begins on the north wall with Christ the Righteous Judge in a Deisis (the Last Judgement just above), spreads across the east wall (above it is the ruling family before an enthroned Christ), the south and the west wall (beneath the cycle of 'Axo-

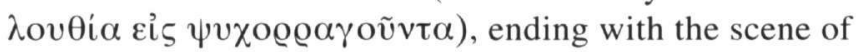
Joseph's death located beneath the Last Judgement. The placement of Joseph's cycle beside that tied to the deliverance of the soul is certainly not accidental: as was accurately noticed ${ }^{44}$, they are mutually complementary in representing an Old Testament model of a just and honorable life of a Christian believer and a model death of a Christian monk, whose soul is the subject of a duel between angels and demons. In the end, before Christ, the soul of each gains its place in heaven. Life on earth is made up of constant confrontations of good and evil, the inclination towards sin and its evasion, which is described as a conflict between demons and angels. Such is, also,

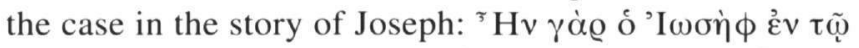

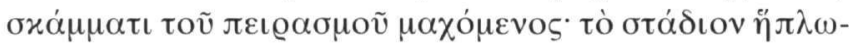

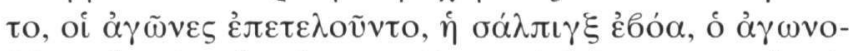

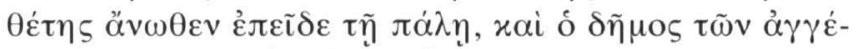

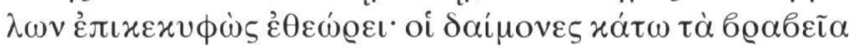

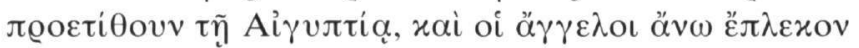

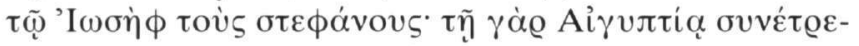

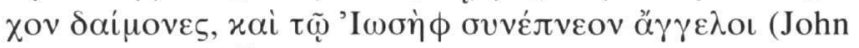

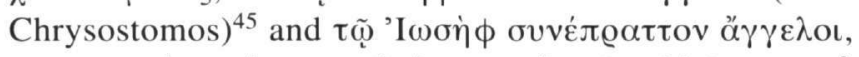

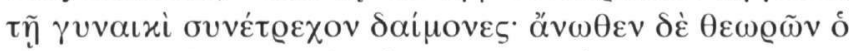

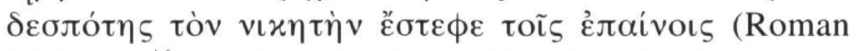

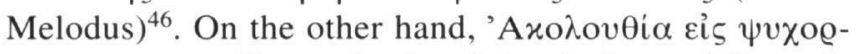

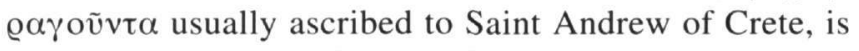
full of descriptions of angels fighting demons over the souls of the righteous ${ }^{47}$, meticulously transposed into painting by the masters working in Ohrid, and those working at a somewhat earlier date in the church of St George in Chilandar ${ }^{48}$.

It can, thus, be concluded, from all of the above, that the original illustrative-anectodal character of the Joseph cycle becomes, at some time around the ninth century, enriched with new meanings. On the one hand, its didactic significance is emphasized, Joseph becoming an exemplary righteous undergoing various temptations only to triumph in the end. The cycle is, thus, almost never left without the scenes of "Brothers Selling Joseph Off", "Joseph's Chastity" and "Joseph's Triumph", while its other episodes remain variable and inconstant. On the other hand, the cycle retains its christological meaning, apparent already in monuments of the Constantinian era, but altered to a considerable extent under the influence of religious services and the writings of the Church fathers. In Sopoćani, where the cycle follows the text of St
Ephraim the Syrian, its undisputed didactic meaning is topped by a christological significance resulting from its disposition between the Tree of Jesse and the Last Judgement, none the less, after all, from its very location in the narthex itself.

The influence of the liturgy on paintings of Joseph is best attested by the inclusion of his figure among the Old

(note 3), p. 33. Both authors agree with R. Ljubinković (Sur le symbolisme de l'histoire de Joseph du narthex de Sopoćani, L'art byzantin du XIIIe siècle, Symposium de Sopoćani 1965, Belgrade 1967, p. 207-237) whose allegorical interpretation of the cycle as a whole and each separate scene in particular, in connection with the biographies of the Serbian saints Simeon Nemanja and Sava, is, by no means, acceptable: drawing parallels between these Serbian saints, their lives and deeds, and the lives and deeds of the Old Testament righteous and saints in general, is considered a locus generalis of all medieval hagiographies. It is not clear why, after a good analysis of the cycle, Mrs. Z. Gavrilović (op.cit. (note 23), p. 48-50) still accepts the thesis of Ljubinković.

35. "Das ganze Leben des ägyptischen Joseph ist hier das Vor-Bild des Lebens Christi... Der Josephzyklus in Sopoćani ist ein klassisches Beispiel für die Anwendung der Typologie in doppelter Beziehung im Dienste eines typisch mittelalterlichen Denkens der Gegenwart sub specie aeternitatis", Ham a n - M a c Le an, op.cit. (note 26), p. 186187.

36. Tvorenija iže vo svjatih otca našego Efrema Sirina, II, p. 116.

37. Ibid., p. 117.

38. Ibid., p. 119.

39. The partly preserved inscription by the scene (...pade na grob) is analogous to Ephraim's text: "And as soon as Joseph saw the sepulchre of his mother Rachel, running, he fell on the grave...", ibid., p. 124.

40. V. R. P e t k o v i ć (Priča o Prekrasnom Josifu u Sopoćanima, 42) and R. Lj u binkovi ć (op.cit. (note 34), p. 211, 217-219) speak of a direct influence of the apocryphal texts on Joseph and Assenet on the fresco in Sopoćani; however, it appears here due to Ephraim's sermon on Joseph, cf. G a th i e r-W alt er, op.cit. (note 3), p. 32.

41. Mercenier,op.cit. (note 18), p. 99.

42. Cf. Gauthie r-W al te r, op.cit. (note 3), p. 32-34 (with previous bibliography).

43. The cycle in Ohrid was best described and explained by $\mathrm{C}$. Grozdanov, Ohridsko zidno slikarstvo XIV veka, Belgrade 1980, p. 94-100, figs 63-67. His only unadoptable thesis is that of a connection between the cycle and the contemporary legal acts of the Emperor Stefan Dušan.

44. S. R a dojči ć, "Čin bivajemi na razlučenije duši od tela" u monumentalnom slikarstvu XIV veka, ZRVI 7 (1961), p. 47. V. J. Djuri ć, Vizantijske freske u Jugoslaviji, Belgrade 1974, p. 68. Grozdanov, op.cit., p. 100.

45. PG, 56, col. 588

46. R oman os le Mélode, Hymnes, I, p. 278.

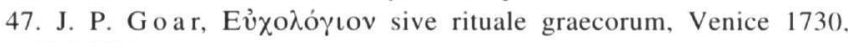
p. $585-587$.

48. R a d o j č i ć, op.cit., p. 44; G roz d a n o v, op.cit., p. 89, drawings 24-25. 
Testament righteous and forefathers in Palaeologan art. We have made an attempt to explain that phenomenon, as well as the renewal of the cycle in wall painting during the last centuries of Byzantine art, on the basis of liturgical readings, above all, the sermons of St Ephraim the Syrian and St John Chrysostomos and hymns of the Sunday of the Holy Ancestors and those of Good Monday. Il- lustrations of Joseph's life found in psalters of the ninthfourteenth century, accompanying Psalm CIV (CV) are most often taken over from cycles based on the text of the Genesis. The iconography of any particular scene from those psalters and those cycles was not the matter of our study, because that problem requires specialized and considerably more extensive studying. 